\title{
ARTÍCULOS
}

\section{WHAT DO POLITICIANS DO ON TWITTER? FUNCTIONS AND COMMUNICATION STRATEGIES IN THE SPANISH ELECTORAL CAMPAIGN OF 2016}

\author{
¿Qué hacen los políticos en Twitter? \\ Funciones y estrategias comunicativas en la \\ campaña electoral española de 2016
}

Amparo López-Meri, Silvia Marcos-García and Andreu Casero-Ripollés

Nota: Este artículo se puede leer en español en:

http://www.elprofesionaldelainformacion.com/contenidos/2017/sep/02_esp.pdf
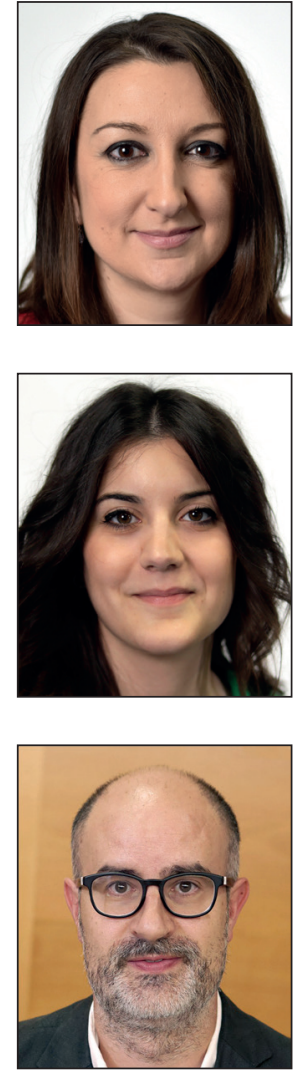

Amparo López-Meri has a PhD in Journalism and is a lecturer in the Department of Communication Sciences at the Universitat Jaume I de Castelló (Spain). Her lines of research focus on the reformulation of journalism and political communication in the digital environment. She also researches in fields such as media ethics and innovation in higher education. She participates in research projects financed by the Ministry of Economy and Competitiveness of Spain. For twelve years she worked as a journalist and news editor in Spanish media.

http://orcid.org/0000-0003-3408-2190

meri@uji.es

Silvia Marcos-García has a degree in Journalism and a Master's in New Trends and Processes of Innovation in Communication from Universitat Jaume I de Castelló (Spain). She is a doctoral student in Communication Sciences and FPI fellow from the Generalitat Valenciana (VALi + D program). Her lines of research focus on political communication and journalism in social networks.

http://orcid.org/0000-0003-1682-1009

smarcos@uji.es

Andreu Casero-Ripollés is an associate professor of Journalism and director of the Department of Communication Sciences of the Universitat Jaume I de Castelló (Spain). He has a degree from the Universitat Autònoma de Barcelona and holds a PhD from the Universitat Pompeu Fabra. He is a member of the Institute of Catalan Studies. He has been a visiting researcher at the universities of Columbia (United States) and Westminster (UK), among others. He works on the transformations of digital journalism and political communication, and has published in the journals Information, communication \& society; International journal of press/politics; American behavioral scientist; and International journal of communication, among others.

http://orcid.org/0000-0001-6986-416

casero@uji.es

Universitat Jaume I de Castelló, Facultat de Ciències Humanes i Socials, Departament de Ciències de la Comunicació Avda. Vicent Sos Baynat, s/n. 12071 Castelló de la Plana, Spain

\section{Abstract}

Twitter has been incorporated as an essential tool in the communication strategies of political actors. However, we need to know more about its use. Our objective is to analyze the main functions attributed to Twitter in electoral campaigns. We studied the 2016 election in Spain based on an analysis of quantitative content. The sample consists of 9,042 tweets, published by the four parties that received the most votes and their candidates. The results show: First, the most widely used 
function was the dissemination of political proposals. Second, a low level of personalization was detected. Third, there was an incipient tendency towards hybridization between new and conventional digital media in the use of this platform. Finally, it was shown that the functions given to Twitter are conditioned, in different ways, by three factors: the historical trajectory of the party, its position on the government-opposition line, and the individual or collective dimension.

\section{Keywords}

Political communication; Electoral campaigns; Social media; Social networking sites; Twitter; Personalization; Hybridization; Digital media.

\section{Resumen}

Twitter se ha incorporado como un canal imprescindible en las estrategias comunicativas de los actores políticos. Sin embargo, necesitamos saber más sobre su uso. Nuestro objetivo es analizar las principales funciones atribuidas a Twitter en campaña electoral. Para ello, mediante el análisis de contenido cuantitativo se estudian las elecciones de 2016 en España. Integran la muestra 9.042 tweets, publicados por los cuatro partidos más votados y sus candidatos. Los resultados muestran: Primero, la función más usada es la difusión de sus propuestas políticas. Segundo, se detecta un bajo nivel de personalización. Tercero, se observa una tendencia incipiente hacia la hibridación entre los nuevos medios digitales y los convencionales en el empleo de esta plataforma. Finalmente, se demuestra que las funciones otorgadas a Twitter se ven condicionadas por tres factores de manera diversa: la trayectoria histórica del partido, su posición en el eje gobierno-oposición y la dimensión individual o colectiva.

\section{Palabras clave}

Comunicación política; Campaña electoral; Medios sociales; Redes sociales; Twitter; Personalización; Hibridación; Medios digitales.

López-Meri, Amparo; Marcos-García, Silvia; Casero-Ripollés, Andreu (2017). "What do politicians do on Twitter? Functions and communication strategies in the Spanish electoral campaign of 2016". El profesional de la información, v. 26, n. 5, pp. 795-804.

https://doi.org/10.3145/epi.2017.sep.02

\section{Introduction}

Politicians have incorporated Twitter as an essential tool in their communication strategies and use it intensely during election campaigns. Since the U.S. elections of 2008, marked by Barack Obama's innovative use of social media, the influence of these digital platforms on political communication has continued to grow in all advanced democracies (Bimber, 2014). However, apart from the theoretical possibilities they allow, we need to know more about the practical use that parties and political leaders have given to social media. A considerable amount of past research has focused on analyzing the reasons for adopting Twitter, the extent to which adoption takes place, and the subjects that politicians tackle in this network (Grusell; Nord, 2012; Enli; Skogerb $\emptyset$, 2013; Graham; Jackson; Broersma, 2016). However, less attention has been paid to the functions attributed to the platforms as part of the communication strategies of the parties and their leaders. An investigation into this topic will allow us to learn about the changes that these technologies are introducing, both in the management of political communication and in today's societies.

The aim of this article is to analyze the main functions that politicians assign to Twitter in the electoral context. We intend to find out what they do on this social media platform and what the implications are for political communication. To do this, we will use a methodology based on analyzing quantitative content to study the 2016 election campaign in Spain. The sample consists of the four most popular parties and their respective candidates, which together, received $89.95 \%$ of the votes.

\subsection{Functions of Twitter in an election campaign}

In the past several years, the use of social media in election campaigns has been studied (Aragón et al., 2013; Jungherr, 2014). The bibliography initially has identified some of the functions fulfilled by Twitter in the communication strategy of the parties and their candidates (Parmelee; Bichard, 2012). The key function is the dissemination of policy statements and information about campaign activities (Jackson; Lilleker, 2011). There is a predominance of self-referencing in social media that manifests itself, for example, when candidates announce their participation in rallies or provide their own links (Criado; Martínez-Fuentes; Silván, 2013).

The use of Twitter is conditioned by three factors: historical trajectory of the party; position in the government-opposition axis; and the individual or collective dimension of the political agent who issues the messages

Parties and their leaders also use Twitter to mobilize voters and encourage participation (Gainous; Wagner, 2014). This function translates into specific requests for users to attend campaign events, work together as volunteers, make economic donations, and vote.

Interaction with the public is another important feature. Twitter offers candidates the possibility of establishing two-way communication between politicians and citizens, 
although it is important to note that there is insufficient evidence to prove that this actually occurs (Stromer-Galley, 2014; Alonso-Muñoz; Marcos-García; Casero-Ripollés, 2017). Although there is exceptions, there is limited interaction on Twitter (Alonso-Muñoz; Miquel-Segarra; Casero-Ripollés, 2016). In some countries, politicians interact more with other politicians and journalists than with the people (Graham et al., 2013).

Another function that Twitter provides is personalization, which is connected to the loss of privacy. Politicians share details of their private lives, thoughts, and emotions (Vergeer; Hermans; Sams, 2013). This function helps to humanize candidates in the eyes of their social audience (Bentivegna, 2015). To gain empathy from voters, some politicians use an informal tone and humor (López-Meri, 2016). They also like to share images, which stimulated more comments and retweets than political statements (Enli; Skogerbø, 2013).

Politicians intensify their use of social media during election campaigns (Abejón-Mendoza; Sastre-Asensio; Linares-Rodríguez, 2012). When users are exposed to messages from candidates their impression of the candidates tends to improve (Hamby, 2013). Therefore, the functions ascribed to Twitter take on key roles during these periods.

This leads to our first research question (RQ):

RQ1: What were the most prominent functions in the communication strategies of the Spanish parties and candidates on Twitter in the 2016 election?

The following hypothesis is proposed in relation to this question:

$\mathrm{H} 1$ : The dominant function in the 2016 election was the dissemination of information about public policies.

The use of Twitter to spread political proposals is based on a double strategy: self-referential messages posted in a positive tone that are complemented by criticisms of the adversary

\subsection{Personalization of politics}

The personalization of politics focuses the discourse on individuals rather than parties (Rahat; Sheafer, 2007). This promotes the candidate's attributes and downplays the importance of ideologies as a differentiating factor between parties, which reduces politics to a clash of personalities (Sánchez-Murillo, 2005).

Mainstream media, especially television, has been the key to personalization (Blumler; Kavanagh, 1999). The parties simplify their speech to reach a mass audience (Holtz-Bacha, 1999), thus adapting to audio-visual language and media logic. For this reason, the mediatization of politics (Mazzoleni; Schulz, 1999) drives the personalization process (Rodríguez-Virgili; Jandura; Rebolledo-de-la-Calle, 2014).

The parties have also contributed to this phenomenon by featuring a leader's personality over his ideology to capture votes (Farrell, 1996). Personalization can take shape in two dimensions: individualization and privacy (Van-Aelst; Sheafer; Stanyer, 2012). The first, individualization, articulates the communication strategy around the candidate (McAIlister, 2007). The second, privacy, emphasizes the politician's personal side. His hobbies, his family life, and even his appearance are more interesting than his leadership skills and his role as an institutional representative (Reinemann; Wilke, 2007). Personalization can also be negative when criticisms of the political rival are focused on its leader and not on the party and its values and ideology (Elmelund-Præstekær; Mølgaard-Svensson, 2014).

Social media also allow for personalization, when politicians make an individualized and personal use of these platforms. In this regard, another of the qualities of digital networks that drives this phenomenon is the ability to address the people directly, and thus get much closer to them (Kruikemeier et al., 2013; López-García, 2016).

This leads to the possibility of asking a second question in our research:

RQ2. To what extent did Spanish parties and politicians tend to personalize the 2016 election on Twitter?

This leads us to the following hypotheses:

H2. There was a high degree of personalization in the 2016 election campaign on Twitter thanks to this platform's ability to promote an individualized use and connect politicians directly to the people.

\subsection{Old and new media logic}

Hybridization in political communication means combining the potential of the digital environment with the logic of mainstream media (Chadwick, 2013). Politicians are not abandoning or replacing traditional tools and tactics. They are enriching them with the new dynamics and possibilities offered by social media (Casero-Ripollés; Feenstra; Tormey, 2016). These platforms provide new ways to participate in political activity (Castells, 2009).

The symbiosis between old and new media logics can be seen in events such as the televised election debates, which recorded the highest number of retweets and comments (Anstead; O'Loughlin, 2011). The peaks in activity on Twitter coincided with the broadcast of political content via mainstream media (Larsson, 2016). This implies that Twitter expands the scope of media coverage of events in the campaign (Lilleker; Jackson, 2010).

There is a third question in our research regarding this matter:

RQ3: To what extent did parties and candidates promote the hybridization of old and new media on Twitter in the 2016 election?

In this respect, the following is assumed:

H3: The parties and their candidates used Twitter to promote their appearances in mainstream media during the 2016 election, stimulating hybridization between old and new media. 


\section{Methodology}

The methodology is based on an analysis of quantitative content, a technique that allows one to have an objective and systematic understanding of the content of the messages analyzed Piñuel-Raigada, 2002; (Igartua, 2006). The sample for this research focuses on the election campaign for the general elections in Spain on the $26^{\text {th }}$ of June, 2016. This analysis is conducted on the 15 official days of the election campaign, followed by the day of reflection, the day of voting, and the day afterwards. During this period, we study all the tweets published by the Partido Popular (the Popular Party, or PP), the Partido Socialista (Socialist Party, or PSOE), Podemos, and Ciudadanos (C's); and their respective candidates, Mariano Rajoy, Pedro Sánchez, Pablo Iglesias, and Albert Rivera. Thus, we analyze a total of 9,042 tweets.

The choice of these four political parties and their leaders meets two criteria. On the one hand, they were the four most popular political choices in the 2016 election and, together, they represented $89.95 \%$ of the votes. On the other hand, these are politicians with clearly differentiated trajectory. While $P P$ and $P S O E$ are the two parties with the longest histories in the Spanish political system, Podemos and Ciudadanos are two emerging parties. This allows us to compare the strategies of two parties that represent traditional politics with two linked to new politics.

The sample data have been extracted using the Tweetonomy tool. The statistical treatment of the results was done using SPSS (v.23). Intercoder reliability was calculated with Scott's Pi formula, reaching a level of 0.97 .

Table 1 shows the analysis protocol used for this research. A number of variables were created for this, and mutually exclusive categories were defined for each of them.

\section{Results}

The results of the analysis of the tweets published by parties and leaders identify the main functions given to Twitter (RQ1).

\section{Proposal of public policies}

The first significant finding is that, other than Pablo Iglesias, all of the political actors used this social networking platform mainly to provide information about their proposals and their election program (Table 2). The PP (39.5\%) and the PSOE (37.3\%), as well as their leaders, Mariano Rajoy (32.4\%) and Pedro Sánchez (22.1\%), used it in a very similar way and devoted a third of their tweets to this function. Ciudadanos and Albert Rivera also agreed when it came to prioritizing the program proposals in their Twitter speeches, since they were present in $41 \%$ and $14.6 \%$ of their tweets, respectively. Podemos and Iglesias, on the other hand, made unequal use of Twitter. The party devoted $31.1 \%$ of its messages to its electoral program and proposes. However, the leader only did it in $6.9 \%$ of messages.

The strategy for disseminating public policy proposals was reinforced with two other complementary functions. The first was community building based on values and ideology (table 2). The Spanish parties and their leaders devoted part of their publications to extolling and strengthening their values as political parties, with tweets in which they used the rhetoric, language, and symbolism directly related to their political ideology. Podemos (12.9\%) and Ciudadanos (7.4\%) along with Iglesias (6.9\%) and Rivera (6.8\%), as the representatives of the new politics, were the ones who used this function the most, with discourses focused on the ideas of 'change' and 'political regeneration'. This dynamic is explained by the fact that they were political actors who had little experience, so they needed to open up and consolidate

Table 1. Analysis protocol used in the research

\begin{tabular}{|c|c|c|}
\hline \multicolumn{2}{|c|}{ Function } & Tweets content \\
\hline \multicolumn{2}{|c|}{$\begin{array}{l}\text { Political agenda } \\
\text { (organization of political events) }\end{array}$} & Information about campaign events (place, time, etc.). \\
\hline \multicolumn{2}{|l|}{ Program/promises } & Including part of the program or election proposals. \\
\hline \multicolumn{2}{|c|}{ Political achievements of management/opposition } & Praise the achievements of the party and/or the leader. \\
\hline \multicolumn{2}{|c|}{ Criticism of the adversary } & Direct attacks on the actions and/or the ideology of other parties or politicians. \\
\hline \multicolumn{2}{|l|}{$\begin{array}{l}\text { Media agenda } \\
\text { (media information) }\end{array}$} & $\begin{array}{l}\text { Links to the media, for example, to share an interview or discussion in which the leader or } \\
\text { another member of the party took part. }\end{array}$ \\
\hline \multicolumn{2}{|c|}{ Interaction/dialogue with users } & The party or leader responds to or asks another user by using the mention (@). \\
\hline \multicolumn{2}{|c|}{ Participation and mobilization } & Asking for votes, donations, or the mobilization of voters or volunteers. \\
\hline \multirow{3}{*}{ Community building } & Values and ideology & Extol and enhance the values and ideology of the party. \\
\hline & Personal life / backstage & $\begin{array}{l}\text { Aspects of the private lives of politicians (hobbies, tastes, family, etc.), which show a more } \\
\text { humane and personal attitude, or which show aspects of the campaign backstage (meet- } \\
\text { ings, travel, etc.). }\end{array}$ \\
\hline & Entertainment & Reaching users through entertainment. \\
\hline \multicolumn{2}{|l|}{ Humor } & Including memes, jokes, and other humorous resources. \\
\hline \multicolumn{2}{|l|}{ Courtesy/protocol } & Appreciation, condolences, anniversaries, etc. \\
\hline \multicolumn{2}{|l|}{ Other } & Content that cannot be classified in any of the above categories. \\
\hline
\end{tabular}


Table 2. Function of the tweets published by the parties and their leaders (\%)

\begin{tabular}{|c|c|c|c|c|c|c|c|c|}
\hline & PP & Rajoy & PSOE & Sánchez & Podemos & Iglesias & C's & Rivera \\
\hline Agenda and organization of political actions & 7.5 & 17.0 & 1.4 & 9.3 & 9.2 & 7.9 & 5.6 & 10.7 \\
\hline Electoral Program & 39.5 & 32.4 & 37.3 & 22.1 & 31.1 & 6.9 & 41.1 & 14.6 \\
\hline Management of political achievements & 12.0 & 6.9 & 5.6 & 2.8 & 6.7 & 3.0 & 4.8 & 2.9 \\
\hline Criticizing opponents & 14.2 & 2.8 & 26.7 & 18.1 & 21.9 & 5.0 & 21.7 & 13.6 \\
\hline Media agenda (media information) & 4.8 & 1.6 & 2.2 & 5.0 & 2.4 & 7.9 & 4.4 & 11.7 \\
\hline Interaction/dialogue with users & 1.3 & 6.0 & 1.5 & 7.8 & 1.4 & 25.7 & 1.7 & 12.6 \\
\hline Participation and mobilization & 11.5 & 20.1 & 14.5 & 17.4 & 9.0 & 9.9 & 7.6 & 10.7 \\
\hline Community building: values and ideology & 5.1 & 3.5 & 9.3 & 4.7 & 12.9 & 6.9 & 7.4 & 6.8 \\
\hline Community building: personal life /backstage & 0.8 & 2.5 & 0.0 & 4.0 & 1.3 & 11.9 & 2.3 & 3.9 \\
\hline Community building: entertainment & 0.7 & 0.6 & 0.1 & 0.9 & 0.4 & 3.0 & 0.0 & 1.0 \\
\hline Humor & 0.2 & 0.3 & 0.1 & 0.3 & 0.1 & 5.9 & 0.0 & 0.0 \\
\hline Manners/protocol & 1.0 & 6.0 & 0.4 & 6.9 & 2.6 & 7.9 & 1.5 & 11.7 \\
\hline Other & 1.4 & 0.3 & 0.8 & 0.6 & 1.0 & 1.0 & 1.7 & 0.0 \\
\hline
\end{tabular}

a new space for communicate their policies in opposition to the traditional parties and leaders, who were already known by the electorate. With respect to the established parties, only the PSOE (9.3\%) was noted for giving prominence to the party's values.

The second complementary function was criticism (Table 2), as both parties and leaders used Twitter as a way of attacking their political opponents. This function was especially used in the profiles of the parties in opposition to the Government led by Partido Popular (People's Party). The PSOE devoted $26.7 \%$ to criticism, Podemos $21.9 \%$, and Ciudadanos $21.7 \%$. Regarding the candidates, while Sánchez (18.1\%) and Rivera (13.6\%) emphasized the use of this function, Iglesias included it in only $5 \%$ of his tweets. PP (14.2\%) and Rajoy $(2.8 \%)$, as representatives of the Government, reduced the use of Twitter to criticize other parties and exploited it as a channel for praising and highlighting their own achievements ( $12 \%$ and $6.9 \%$, respectively).

\section{Pedro Sánchez}

Pedanchescastiejor

2. Segueix

Si el presidente en funciones no cesa de inmediato a \#FernándezDiaz, será responsable de la conducta de su ministro.

PODEmos o
"De Rajoy ya no sorprende lo que dice sino lo
que calla: la desigualdad y la pobreza"
@Lucia_M M26JAdeuPP

Image 1. Tweets criticizing the management of Mariano Rajoy ${ }^{1}$ Source: Twitter
This strategy of criticism was, in most cases, conducted through negative personalization. Attacks were aimed at rival leaders (Image 1) and concentrated on accusations directed to debilitate both them and their political proposals. This personalization also contributed, from a negative viewpoint, to constructing the parties' and the candidates' political offerings on Twitter.

The results show that criticisms usually focused on Mariano Rajoy and on his mandate as president (Image 1). This fact shows that the position of the political actor was a determining factor when it was negatively personalized. Any party that governs, without refusing to attack, is geared more to extolling its own achievements. On the other hand, the parties in opposition prioritized criticizing the government to discredit it.

\section{Citizens' participation and mobilization}

The second most widely used function of Twitter was participation and mobilization, which included tweets asking for votes, calling for donations, or urging people to participate in campaign events (Table 2). Rajoy (20.1\%) and Sánchez (17.4\%), leaders of $P P$ and $P S O E$, respectively, engaged the most in this function. In contrast, the lowest values were detected for Ciudadanos (7.6\%) and Podemos (9\%). The established parties, especially their candidates, were the ones who used this function most, explicitly for canvassing. Emerging politicians used it less, and when they did, they just asked their followers to attend rallies and campaign events.

\section{Personalization}

The use of social media as a mechanism of personalization was limited in the 2016 election (Table 2). It was significant only in the case of Pablo Iglesias, the only candidate who made personal use of Twitter (RQ2). The strategy followed 


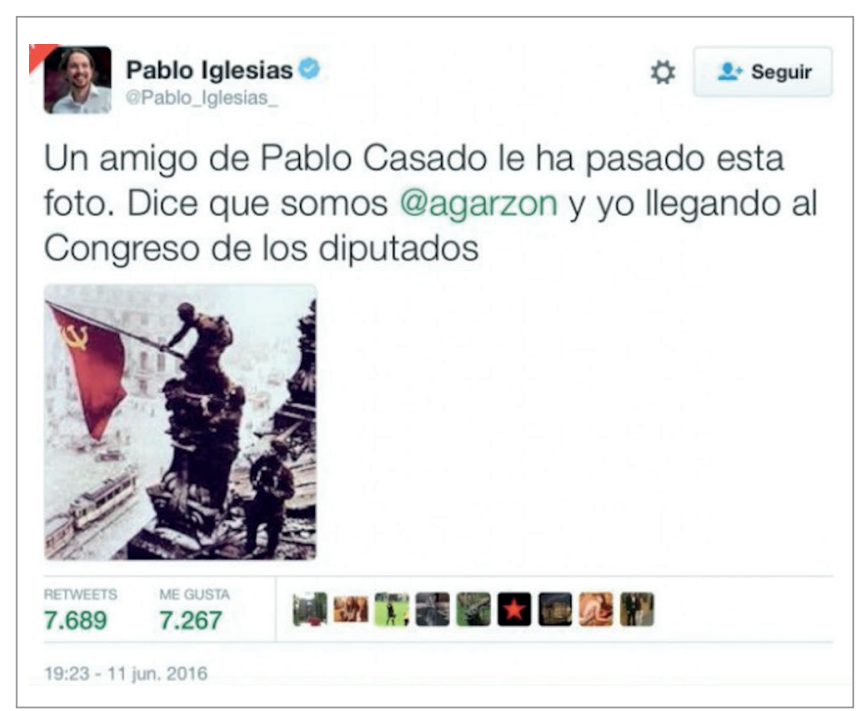

Image 2. Most retweeted tweet of the campaign ${ }^{2}$ Source: Twitter

by the leader of Podemos seemed to be aimed at reaching a direct and close relationship with the people who he interacted with. In fact, $25.7 \%$ of his tweets were answers or questions to other users within his social network. Iglesias's discourse was also notable for including matters relating to his private life. In $11.9 \%$ of his tweets, he shared his tastes, interests, feelings, and emotions.

In Iglesias' account was also common to use jokes and humorous resources $(5.9 \%)$ such as memes or photomontages. The item with the most retweets $(8,054)$ in the entire election campaign was a tweet from Pablo Iglesias in which he joked about his bonding with the leader of Izquierda Uni$d a$, Alberto Garzón, and his communist ideology (Image 2). These data show how Twitter can bolster political spectacle and infotainment. Personal issues and humorous messages are what most attract the users' attention (Berrocal-Gonzalo; Redondo-García; Campos-Domínguez, 2012).

The predominant role attributed to Twitter by all political actors, except in the case of Pablo Iglesias, is the dissemination of political proposals that are part of their electoral program

\section{Hybridization between new and old media}

The results show that there was a hybridization between new and old media in the use of Twitter by politicians. Data relating to the category of 'media agenda', which includes tweets that publicized the involvement of politicians on television or in digital newspapers or news links, show a moderate but incipient use of this function. Pablo Iglesias (7.9\%) and Albert Rivera (11.7\%) were the two leaders who exploited this medium the most (Table 2). A very different dynamic from the one followed by Mariano Rajoy (1.6\%) and Pedro Sánchez (5\%), who hardly used this type of content in their profiles. The parties also did not make much use of this function; they used it between $2 \%$ and $5 \%$.
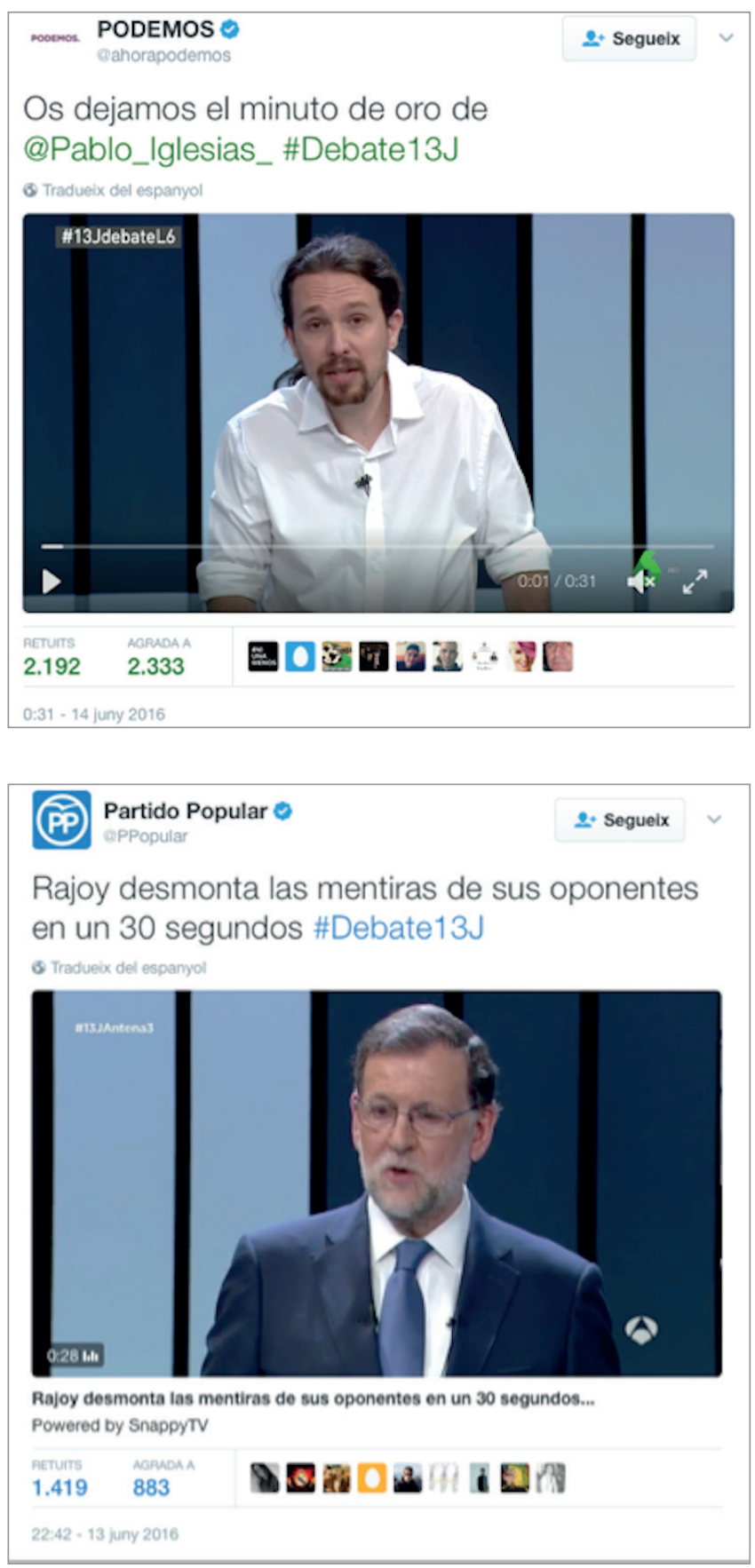

Image 3. Most retweeted tweets of the parties ${ }^{3}$

Source: Twitter

The candidates of the emerging parties were those who employed this strategy of hybridization the most. Twitter acted as a tool through which the leaders of the new politics sought to enhance their media projection. TThis fact reaffirms the importance mainstream media continue to have during election campaigns, even in the digital environment (Casero-Ripollés; Feenstra; Tormey, 2016).

It is worth noting how these hybridization-based messages had a positive impact on the public. Of the five tweets shared by the parties that achieved the most retweets, two alluded to the television debate between the four candidates held on the $13^{\text {th }}$ of June, 2016 and broadcast by several channels -specifically, the golden minute of Iglesias and an intervention of Rajoy (Image 3). 


\section{Conclusions}

The results contain several original contributions that are applicable beyond Spain, thereby increasing knowledge of the functions Twitter provides politicians in the context of electoral campaigning:

- The first is the prominence acquired by dissemination of their political proposals and the importance attached to getting people to participate and mobilize.

- The second is the low degree of personalization of politics that was recorded in politicians' use of this digital platform.

- The third is the emerging trend toward hybridization between new digital media and mainstream media in online communications strategy, especially in the case of parties with a more recent emergence.

It is important to highlight that all these features of Twitter use are conditioned by three key factors:

- the history of the party;

- the position the party occupies in the government-opposition dynamics; and

- the individual or collective dimension of the political actor who broadcasts the messages.

The results show that the predominant role attributed to Twitter by all politicians, except Pablo Iglesias, was the dissemination of the policy proposals that they integrated into their electoral programs (RQ1). Hypothesis 1 was verified in this way. The possibility of addressing people directly, without the participation of journalists and the mainstream media, promoting auto-mediation, is based on the prevalence of this type of use of Twitter. The option of exercising mass self-communication that allows wide dissemination of policy proposals made politicians focus their efforts on this function. Its importance was such that their political trajectory had no impact on this use, boosted equally by established and emerging parties.

\section{Most of the Spanish parties and leaders do not publish tweets that show aspects of their personal lives}

The use of Twitter to broadcast policy proposals was based on a double strategy:

- On the one hand, messages were published with the measures put forward in a positive tone. This was supplemented, in the case of parties linked to the new politics, with the distribution of tweets that highlighted their values and their ideology. This practice was used to emphasize the novelty of what these emerging parties are offering politically: change and democratic regeneration.

- On the other hand, this strategy was complemented by criticizing their adversaries. This was based on negative personalization, as they focused the blame on the leaders of the rival parties. This dynamic depended on the position of the party and on the individual or collective dimension of the political actors. In this way, the opposition parties made a more intense use of reproaching their competitors than the Government $(P P)$. Equally, accusa- tions against opponents were more frequent in party profiles than in the leader's profiles.

Another prominent function is participation and mobilization (RQ1). Its activation depended, to a large extent, on the historical trajectory of the political actors. Contrary to what one might expect, the established parties made greater use of this function than the emerging ones. Moreover, while the former called explicitly for votes in their tweets, appealing to the logic of persuasion, the latter encouraged the people to be involved in the campaign, promoting the logic of mobilization. The individual or collective dimension also appeared as a determining factor, since leaders use this function more than the parties.

Contrary to what is envisioned by hypothesis 2 , the results show a low level of personalization attributed to Twitter by politicians. With the exception of Pablo Iglesias, the other parties and candidates recorded very low use of tweets to publicize their personal lives and contribute to build a community of followers (RQ2). Unlike the findings in previous studies (Van-Santen; Van-Zoonen, 2010; Jackson; Lilleker, 2011; Parmelee; Bichard, 2012; Enli; Skogerb $\varnothing, 2013)$, most parties and leaders in Spain rejected the idea of publishing tweets to display aspects of their private lives, which this way falls outside the media spotlight. Despite the limited use of this function, its use was determined by two factors:

- the individual or collective dimension of the political actors and,

- to a lesser extent, his historical trajectory.

As expected, the leaders had higher values than their parties. Meanwhile, the emerging parties resorted more to personalization on Twitter than the established parties.

This pattern was not followed by the Podemos candidate, who used some tweets to reveal aspects of his private life such as his tastes, interests, feelings, or emotions. He thus sought to humanize his image and get closer to the people (Enli; Skogerbø, 2013). He combined this with resorting to humor through jokes and memes to reinforce that connection. Thus, the function of personalization on Twitter takes on the characteristics of pop politics (Mazzoleni; Sfardini, 2009). This means that political actors incorporate into their communicative repertoires styles, narratives, and staging of the world of spectacle and entertainment. These results indicate that this phenomenon, which is more appropriate for television, is expanding out of its natural habitat and now also extends to the environment of social networks. Although in the Spanish case it only affects Pablo Iglesias, this trend can be a precursor and have a significant influence in the future in building up the image of the political leader in social media. This is an aspect that must be verified through further study.

Analysis of the functions granted to Twitter by parties and candidates during the 2016 election allowed us to detect the still incipient advancement of the hybridization of political communication (Chadwick, 2013) (RQ3). This focuses on the use of new digital platforms for establishing links with the mainstream media. This trend can connect with the category of 'media agenda' and partially verifies hypothesis 3 . Thus, through their profiles on Twitter, politicians can publicize 
their participation on television shows via interviews or discussions, or their appearance on the news to maximize their impact. In this way, they can use a communication strategy that combines and mixes the old and new media in a complementary way. An analysis of this aspect allowed us to identify the important role that both the historical background of the political organizations and the individual or collective dimension had on its activation. Thus, political leaders resorted more to this function than the parties. Furthermore, actors who were linked to emerging parties resorted more intensely to this strategy than well-consolidated parties.

\section{There is a hybridization between new} and old media in the use of Twitter by political agents

The focus on hybridization between old and new media by parties with less historical background can be explained in various ways:

- first, the need to achieve greater impact and projection in their appearances in mainstream media, especially on television. Since access to this media is less frequent for them than it is for the established parties, they seek to maximize profit from these moments;

- hybridization is used to achieve many retweets and 'likes' to ensure a double effect: to obtain better publicity and to become subjects of interest for the media due to the build up of a large audience;

- the emerging parties have their natural habitat on social networks sites but they are also aware of the importance of mainstream media in modern society and the need to connect old and new media (Casero-Ripollés; Feenstra; Tormey, 2016);

- parties want to take advantage of the ability of mainstream media legitimize. For that reason, thanks to their appearances on media, they show themselves as a valid, acceptable, and reliable political option.

Finally, as has been said, the results show that the functions given to Twitter by politicians are conditioned by three factors:

- the history of the party;

- the position it occupies on the government-opposition dynamics;

- the individual or collective dimension of the actor.

The latter factor has a higher incidence since it influences the four most relevant functions discussed in this article:

- proposals of public policies;

- participation and mobilization of the people;

- personalization;

- hybridization between new and old media.

The parties' adherence to the old or new policy, according to their age, affects this whole set of functions, with the exception of the formulation of policy proposals. Instead, position on the government-opposition axis is less predominant, since that determines only the spread of policy proposals. These findings constitute a novel contribution because they reveal various factors that condition political actors to focus more on one function or another on Twitter.

\section{Notes}

1. Pedro Sánchez:

"If the President-in-Office does not immediately stand down \#FernandezDíaz, he will be responsible for the conduct of his minister".

Podemos:

"We are not surprised about what Rajoy says. We are surprised about what Rajoy remains silent: inequality and poverty @Lucia M \#26JAdeuPP".

2. Pablo Iglesias

“Pablo Casado's friend has sent him this photo. He says that we are @agarzon and me arriving to the Congress of the Deputies"

3. Podemos:

"We share the golden minute of @Pablo_Iglesias_\#Debate13J"

Partido Popular:

“Rajoy refutes his opponents' lies in 30 minutes @Debate13J"

\section{Funding}

This article is part of the research project CSO2014-52283C2-1-P funded by the Ministry of Economy and Competition of the Spanish Government, as part of the State Plan for Scientific Research and Innovation 2013-2016.

\section{Bibliography}

Abejón-Mendoza, Paloma; Sastre-Asensio, Ana; Linares-Rodríguez, Virginia (2012). "Facebook y Twitter en campañas electorales en España". Anuario electrónico de estudios en comunicación social Disertaciones, v. 5, n. 1, pp. 129-159.

https://dialnet.unirioja.es/descarga/articulo/5112119.pdf

Alonso-Muñoz, Laura; Marcos-García, Silvia; Casero-Ripollés, Andreu (2017). "Political leaders in (inter)action. Twitter as a strategic communication tool in electoral campaigns". Trípodos, v. 39, pp. 71-90.

https://goo.gl/RqLBJ7

Alonso-Muñoz, Laura; Miquel-Segarra, Susana; Casero-Ripollés, Andreu (2016). "Un potencial comunicativo desaprovechado. Twitter como mecanismo generador de diálogo en campaña electoral". Obra digital, n. 11, pp. 39-58. http://repositori.uji.es/xm/ui/handle/10234/165180

Anstead, Nick; O’Loughlin, Ben (2011). “The emerging viewertariat and $B B C$ question time: Television debate and real-time commenting online". The international journal of press/politics, v. 16, n. 4, pp. 440-462.

https://goo.gl/LcJbFW

https://doi.org/10.1177/1940161211415519

Aragón, Pablo; Kappler, Karolin-Eva; Kaltenbrunner, Andreas; Laniado, David; Volkovich, Yana (2013). "Communication dynamics in Twitter during political campaigns: The case of the 2011 Spanish national election". Policy \& internet, v. 5, n. 2, pp. 183-206.

https://doi.org/10.1002/1944-2866.POI327

Bentivegna, Sara (2015). A colpi di tweet: la politica in prima persona. Bologna: II Mulino. ISBN: 9788815257215 
Berrocal-Gonzalo, Salomé; Redondo-García, Marta; Campos-Domínguez, Eva (2012). “Una aproximación al estudio del infoentretenimiento en internet: origen, desarrollo y perspectivas futuras". AdComunica, n. 4, pp. 63-79.

https://doi.org/10.6035/2174-0992.2012.4.5

Bimber, Bruce (2014). "Digital media in the Obama campaigns of 2008 and 2012: Adaptation to the personalized political communication environment". Journal of information technology \& politics, v. 11, n. 2, pp. 130-150.

https://goo.gl/PjJpVs

https://doi.org/10.1080/19331681.2014.895691

Blumler, Jay G.; Kavanagh, Dennis (1999). “The Third Age of political communication: Influences and features". Political communication, v. 16, n. 3, pp. 209-230.

https://goo.gl/PBW2xA

https://doi.org/10.1080/105846099198596

Casero-Ripollés, Andreu; Feenstra, Ramón A.; Tormey, Simon (2016). "Old and new media logics in an electoral campaign: The case of Podemos and the two-way street mediatization of politics". The international journal of press/ politics, v. 21, n. 3, pp. 378-397.

http://repositori.uji.es/xmlui/bitstream/handle/10234/161683/ casero_2016.pdf?sequence $=1$

https://doi.org/10.1177/1940161216645340

Castells, Manuel (2009). Comunicación y poder. Barcelona: Editorial UOC. ISBN: 9788420684994

https://paisdospuntocero.files.wordpress.com/2015/04/07comunicacic3b3n_y_poder_de_manuel_castells3.pdf

Chadwick, Andrew (2013). The hybrid media system: Politics and power. Oxford University Press. ISBN: 0199759480

Criado, J. Ignacio; Martínez-Fuentes, Guadalupe; Silván, Aitor (2013). "Twitter en campaña: las elecciones municipales españolas de 2011". RIPS: Revista de investigaciones políticas y sociológicas, v. 12, n. 1, pp. 93-113.

http://www.usc.es/revistas/index.php/rips/article/view/1307

Elmelund-Præstekær, Christian; Mølgaard-Svensson, Helle (2014). "Negative and personalized campaign rhetoric: Party communication and media coverage of Danish parliamentary elections 1994-2011". World political science review, v. 10, n. 2, pp. 365-384.

https://goo.gl/QHQips

https://doi.org/10.1515/wpsr-2014-0018

Enli, Gun; Skogerbø, Eli (2013). “Personalized campaigns in party-centred politics: Twitter and Facebook as arenas for political communication". Information, communication \& society, v. 16, n. 5, pp. 757-774.

https://goo.gl/FQ6kte

https://doi.org/10.1080/1369118X.2013.782330

Farrell, David M. (1996). "Campaign strategies and tactics". En: Leduc, Lawrence; Niemi, Richard G.; Norris, Pippa (eds.). Comparing democracies. elections and voting in global perspective. Thousand Oaks: Sage. ISBN: 9780803958364

Gainous, Jason; Wagner, Kevin M. (2014). Tweeting to power: The social media revolution in American politics. Oxford University Press. ISBN: 9780199965076

https://doi.org/10.1093/acprof:oso/9780199965076.001.0001
Graham, Todd; Broersma, Marcel; Hazelhoff, Karin; Van'tHaar, Guido (2013). "Between broadcasting political messages and interacting with voters: The use of Twitter during the 2010 UK general election campaign". Information, communication \& society, v. 16, n. 5, pp. 692-716. https://goo.gl/kHS5ZR https://doi.org/10.1080/1369118X.2013.785581

Graham, Tood; Jackson, Dan; Broersma, Marcel (2016). “New platform, old habits? Candidates' use of Twitter during the 2010 British and Dutch general election campaigns". New media \& society, v. 18, n. 5, pp. 765-783.

http://eprints.whiterose.ac.uk/113492 https://doi.org/10.1177/1461444814546728

Grusell, Marie; Nord, Lars (2012). “Three attitudes to 140 characters the use and views of Twitter in political party communications in Sweden". Public communication review, v. 2 , n. 2, pp. 48-61.

http://epress.lib.uts.edu.au/journals/index.php/pcr/article/ view $/ 2833$

Hamby, Peter (2013). Did Twitter kill the boys on the bus? Searching for a better way to cover a campaign. Joan Shorenstein Center of the Press Politics and Public Policy. Discussion paper series.

http://shorensteincenter.org/d80-hamby

Holtz-Bacha, Christina (1999). "Mass media and elections: An impressive body of research". En: Brosius, Hans-Bernd; Holtz-Bacha, Christina (eds.). German communication yearbook. Nueva Jersey: Hampton Press. ISBN: 9781572732957

Igartua, Juan-José (2006). Métodos cuantitativos de investigación en comunicación. Barcelona: Bosch. ISBN: 97884 97902717

Jackson, Nigel; Lilleker, Darren (2011). "Microblogging, constituency service and impression management: UK MPs and the use of Twitter". The journal of legislative studies, v. 17 , n. 1 , pp. 86-105.

https://doi.org/10.1080/13572334.2011.545181

Jungherr, Andreas (2014). "The logic of political coverage on Twitter: Temporal dynamics and content". Journal of communication, v. 64, n. 2, pp. 239-259.

https://doi.org/10.1111/jcom.12087

Kruikemeier, Sanne; Van-Noort, Guda; Vliegenthart, Rens; De-Vreese, Claes H. (2013). "Getting closer: The effects of personalized and interactive online political communication". European journal of communication, v. 28, n. 1, pp. 53-66.

https://goo.gl/KjfQr8

https://doi.org/10.1177/0267323112464837

Larsson, Anders-Olof (2016). "Online, all the time? A quantitative assessment of the permanent campaign on Facebook". New media \& society, v. 18, n. 2, pp. 274-292.

https://goo.gl/QM1RhC

https://doi.org/10.1177/1461444814538798

Lilleker, Darren G.; Jackson, Nigel A. (2010). “Towards a more participatory style of election campaigning: The impact of web 2.0 on the UK 2010 general election". Policy \& internet, v. 2, n. 3, pp. 67-96. 
https://goo.gl/2gFuAh

https://doi.org/10.2202/1944-2866.1064

López-García, Guillermo (2016). “'New'vs 'old’ leaderships: the campaign of Spanish general elections 2015 on Twitter". Comunicacion y sociedad, v. 29, n. 3, pp. 149-168. https://doi.org/10.15581/003.29.3.149-168

López-Meri, Amparo (2016). “Twitter-retórica para captar votos en campaña electoral. El caso de las elecciones de Cataluña de 2015". Comunicación y hombre, n. 12, pp. 97-118. http://repositori.uji.es/xmlui/handle/10234/163569

Mazzoleni, Gianpietro; Schulz, Winfried (1999). "'Mediatization' of politics: A challenge for democracy?". Political communication, v. 16, n. 3, pp. 247-261.

https://goo.gl/Rvk94e

https://doi.org/10.1080/105846099198613

Mazzoleni, Gianpietro; Sfardini, Anna (2009). Política pop. Da "porta a porta" a "I'isola dei famosi". Bologna: II Mulino. ISBN: 9788815132734

McAllister, Ian (2007). "The personalization of politics". En: Dalton, Russell J.; Klingemann, Hans-Dieter (eds.). The Oxford handbook of political behavior. Oxford: Oxford University Press, pp. 571-588. ISBN: 9780199270125 https://doi.org/10.1093/oxfordhb/9780199270125.003.0030

Parmelee, John H.; Bichard, Shannon L. (2012). Politics and the Twitter revolution. How tweets influence the relationship between political leaders and the public. Lanham, MD: Lexington Books. ISBN: 0739165011

Piñuel-Raigada, José-Luís (2002). “Epistemología, metodología y técnicas del análisis de contenido". Estudios de sociolingüística, v. 3, n. 1, pp. 1-42.

https://goo.gl/aksEk4

Rahat, Gideon; Sheafer, Tamir (2007). "The personalization(s) of politics: Israel, 1949-2003". Political communication, v. 24, n. 1, pp. 65-80.

https://goo.gl/WsMVsE

https://doi.org/10.1080/10584600601128739

Reinemann, Carsten; Wilke, Jürgen (2007). "It's the debates, stupid! How the introduction of televised debates chan- ged the portrayal of chancellor candidates in the German press, 1949-2005". International journal of press/politics, v. 12, n. 4, pp. 92-111.

https://goo.gl/as7Maj

https://doi.org/10.1177/1081180X07307185

Rodríguez-Virgili, Jordi; Jandura, Olaf; Rebolledo-de-la-Calle, Marta (2014). "La personalización de la política en la cobertura mediática: una comparación de las campañas electorales en España y Alemania". Trípodos, v. 1, n. 34, pp. 61-79. http://dadun.unav.edu/handle/10171/40044

Sánchez-Murillo, Luís-Fernando (2005). “El marketing político y sus consecuencias para la democracia". Comunicación y sociedad, n. 4, pp. 11-38.

http://www.comunicacionysociedad.cucsh.udg.mx/index. php/comsoc/article/download/4091/3848

Stromer-Galley, Jennifer (2014). Presidential campaigning in the internet age. Oxford University Press. ISBN: 9780 199731947

Van-Aelst, Peter; Sheafer, Tamir; Stanyer, James (2012). "The personalization of mediated political communication: A review of concepts, operationalizations and key findings". Journalism, v. 13, n. 2, pp. 1-18.

https://goo.gl/i7uwgy

https://doi.org/10.1177/1464884911427802

Van-Santen, Rosa; Van-Zoonen, Liesbet (2010). The personal in political television biographies. Biography, v. 33, n. 1, pp 46-67.

https://repub.eur.nl/pub/20200

Van-Zoonen, Liesbet; Holtz-Bacha, Christina (2000). "Personalisation in Dutch and German politics: The case of talk show". Javnost-the public, v. 7, n. 2, pp. 45-56.

https://goo.gl/VC2iBQ

https://doi.org/10.1080/13183222.2000.11008743

Vergeer, Maurice; Hermans, Liesbeth; Sams, Steven (2013). "Online social networks and micro-blogging in political campaigning: The exploration of a new campaign tool and a new campaign style". Party politics, v. 19, n. 3, pp. 477-501.

https://goo.gl/AqAnjF

http://dx.doi.org/10.1177/1354068811407580

\section{Cronología de la Documentación Española}

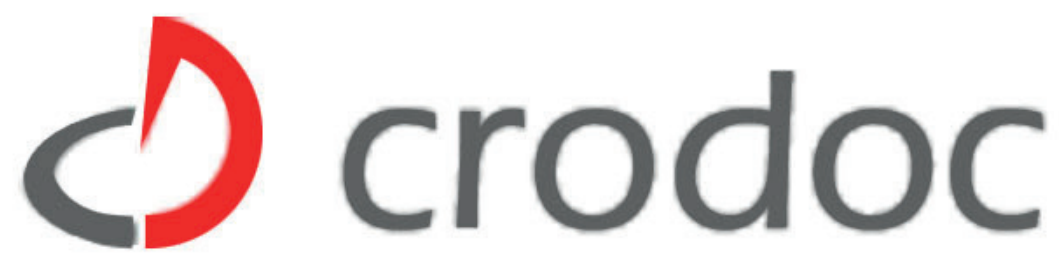

https://www.crodoc.es 